\title{
ECONOMIC GROWTH AND INVESTMENT ACTIVITY AS BASIC ELEMENTS AND INDICATORS OF ECONOMIC SECURITY AND THEIR RELATIONSHIP WITH NATIONAL AND INTERNATIONAL SECURITY
}

\author{
Elitsa PETROVA \\ "Vasil Levski" National Military University, Veliko Tarnovo, Bulgaria \\ elitsasd@abv.bg
}

\begin{abstract}
The economic potential of a country is directly related to a policy of creating new jobs, increasing labour productivity, balancing energy and materials consumption, technological innovation, refurbishing the production base, and taking action to create an environment for attracting investment and stimulating domestic consumption, as well as increasing exports of goods and services. A key feature of the economic system, that determines its ability to maintain normal living and working conditions for the population, is to guarantee and protect the sustainable development of the economy and the realisation of national economic interests. This article is addressed to two main economic security indicators - economic growth and investment activity of the state. It presents a specific comparison of real GDP per capita and growth rate in the European Union, the Eurozone and the Republic of Bulgaria and GDP per capita in purchasing power standards in the European Union, the Eurozone and the Republic of Bulgaria. The flow of foreign direct investment by economic sectors in the Republic of Bulgaria is been considered, including annual data, foreign direct investment flows by countries and the international position of the Republic of Bulgaria in this process.
\end{abstract}

Keywords: gross domestic product, economic growth, investment activity, economic security, national security, international security

\section{Introduction}

The economic security of the country must be guaranteed by the efficiency of the economic system itself. The criterion of economic security is the assessment of the state of the economy in terms of the most important processes and elements expressing the essence of the economic system. The highest level of security can be achieved when the entire set of indicators is within the limits set by available theory and practice. Therefore, we will focus on some of the key economic indicators such as economic growth rates, gross domestic product, investment activity and levels of foreign direct investment. One of the major factors that greatly predetermine many of the country's economic characteristics is the level of its economic development, determined by the rates and growth of the gross domestic product created within its limits, which is a measure of the market value of the final output of the production activity in the economy for a given period. Investment activity has also a direct impact on the level of economic security. The low investment activity can be seen as a direct threat to the economic foundations as it provides the sources of growth, generates revenue to the state budget, and ultimately guarantees the financing of national security as a whole. 
2. Gross Domestic Product and Economic Growth

Gross Domestic Product (GDP) is a measure of the quantity of goods and services produced over a given period of time in a given geographical area. It is an economic indicator of measuring national income, national output, the standard of living of a particular nation, and, on that basis, the emergence of the economic growth of the state. The values of this indicator depend on the level and quality of life [1], business [10], education, healthcare, country's financial capabilities, country's defence capabilities [4], and development of science and culture. That is why the level of economic growth [9] is one of the main and most important indicators of economic security of the country.

Each national territory has a foreign business that is part of the GDP. A distinction has to be made between GDP and gross national product, including income from investment abroad. GDP per capita shows on average the quantity of goods and services per person in a given country.

Table 1 Actual GDP per capita and Growth Rate in chain volumes (2010)

\begin{tabular}{|c|c|c|c|c|c|c|c|c|c|c|}
\hline \multirow{2}{*}{ Geographical unit } & \\
\hline & 2007 & 2008 & 2009 & 2010 & 2011 & 2012 & 2013 & 2014 & 2015 & 2016 \\
\hline EU ( 28 countries $)$ & 26200 & 26200 & 25000 & 25500 & 25800 & 25700 & 25700 & 26100 & 26600 & 27000 \\
\hline Eurozone (19 countries & 29400 & 29400 & 28000 & 28500 & 28900 & 28600 & 28400 & 28800 & 29300 & 29700 \\
\hline Eurozone (18 countries) & 29600 & 29600 & 28200 & 28700 & 29100 & 28700 & 28600 & 28900 & 29400 & 29800 \\
\hline Bulgaria & 4900 & 5200 & 5100 & 5200 & 5300 & 5300 & 5400 & 5500 & 5800 & 6000 \\
\hline
\end{tabular}

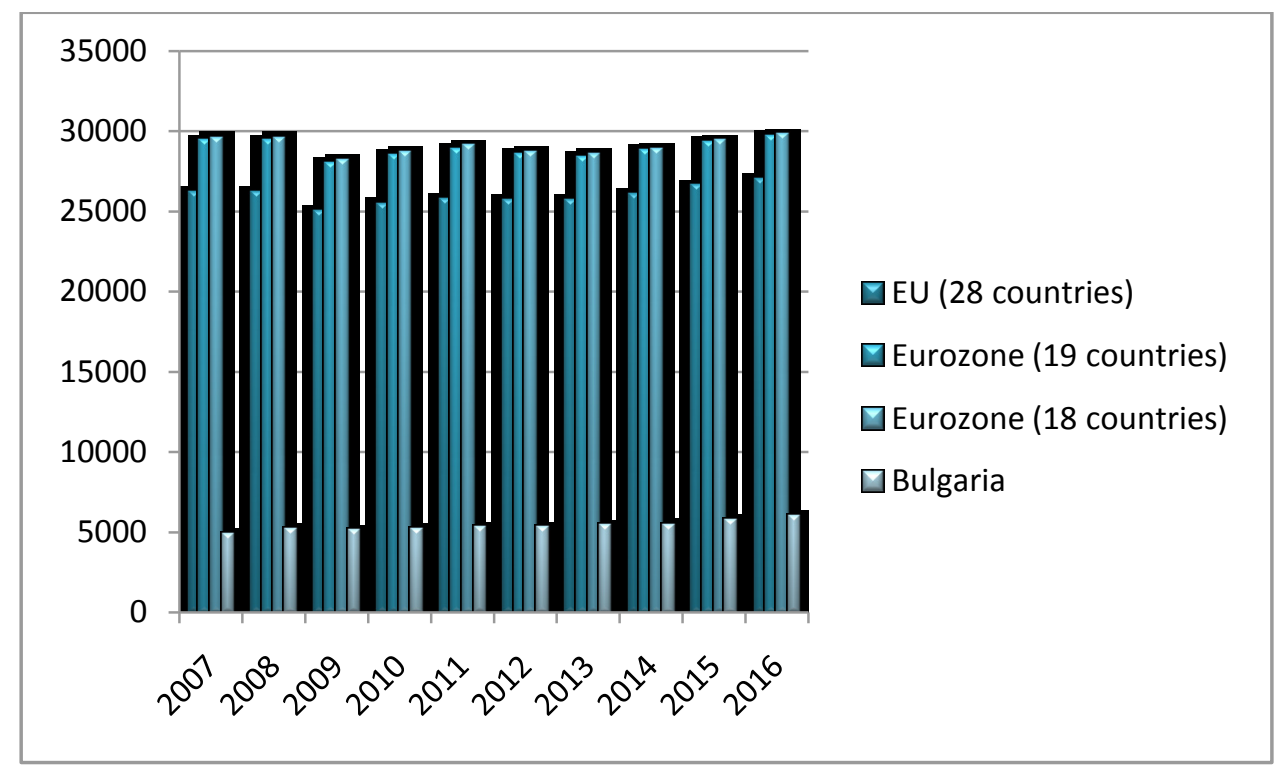

Figure 1: Actual GDP per capita and Growth Rate - Comparison

The low or negative value of this indicator is an expression of the fact that the national economy is unable to mobilize the economic resources at its disposal to use them efficiently and to create the product that society needs to meet its needs. The low rates of GDP growth and, respectively, low or insignificant economic growth, reflect both economic and national security. 
Table 2 GDP per capita in Purchasing Power Standards

\begin{tabular}{|l|l|l|l|l|l|l|l|l|l|l|}
\hline \multirow{2}{*}{ Geographical unit } & \multicolumn{9}{|c|}{} \\
\cline { 2 - 13 } & $\mathbf{2 0 0 7}$ & $\mathbf{2 0 0 8}$ & $\mathbf{2 0 0 9}$ & $\mathbf{2 0 1 0}$ & $\mathbf{2 0 1 1}$ & $\mathbf{2 0 1 2}$ & $\mathbf{2 0 1 3}$ & $\mathbf{2 0 1 4}$ & $\mathbf{2 0 1} 5$ & $\mathbf{2 0 1 6}$ \\
\hline EU (28 countries) & 100 & 100 & 100 & 100 & 100 & 100 & 100 & 100 & 100 & 100 \\
\hline European Union (27 countries) & 100 & 100 & 100 & 100 & 100 & 100 & 100 & 100 & 100 & 100 \\
\hline Eurozone (19 countries) & 109 & 109 & 109 & 108 & 108 & 107 & 107 & 107 & 106 & 106 \\
\hline Eurozone (18 countries) & 110 & 109 & 109 & 108 & 108 & 108 & 107 & 107 & 107 & 106 \\
\hline Bulgaria & 41 & 43 & 44 & 45 & 45 & 46 & 46 & 46 & 47 & 48 \\
\hline
\end{tabular}

Source: http://www.nsi.bg/bg [3]

Examining real GDP per capita and its pace of growth in chain volume from 2010 in euro per capita and GDP per capita in purchasing power standards outlines the tendency for a slight but gradual upsurge in its levels. In this situation, the projected growth rates may be perceived as available but insufficient to achieve changes in the development of the Bulgarian economy. However, they show that, despite the conditions of instability and fluctuations at national level, the economy of the Republic of Bulgaria is slowly recovering and registering growth rates of gross domestic product.

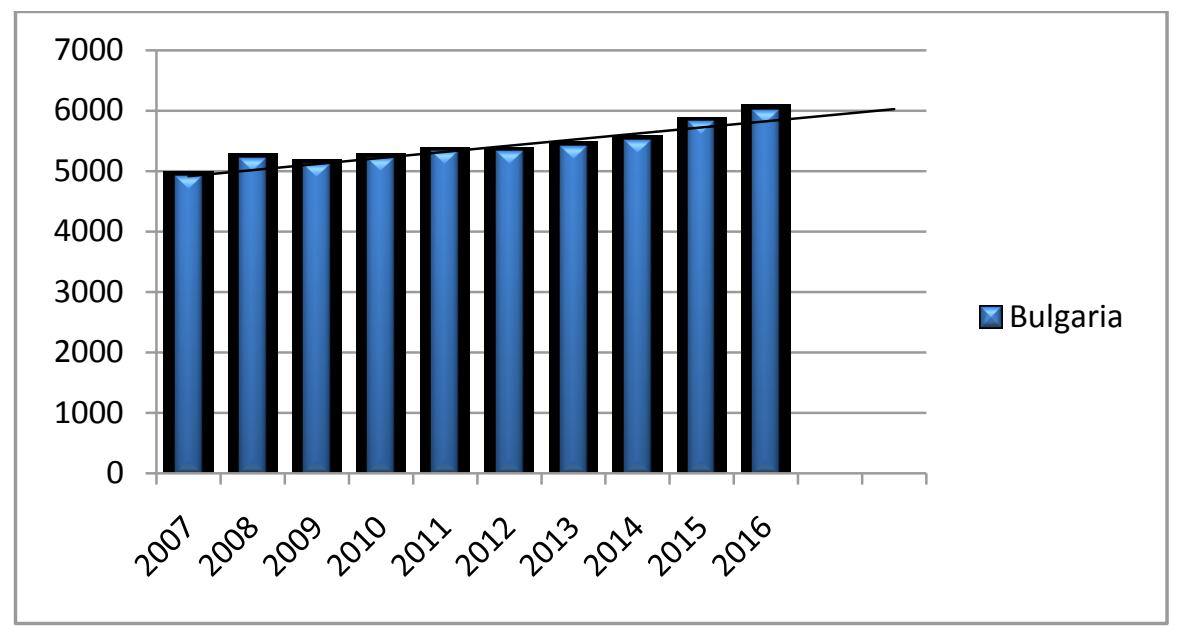

Figure 2: Real GDP per capita and Growth Rate, Levels for the Republic of Bulgaria euro per capita /linear forecasting trend line /

The prognosis for the surveyed indicators is evident from the outlined trend line for linear forecasting. Figure 1 and figure 2 show that in the following years the trend line will have a smooth growth.

\section{Investment activity and Foreign Direct Investment Flows}

Foreign direct investment is defined as the net inflow of investments and the ownership of $10 \%$ or more of the registered share in an enterprise in a different economy from that of the investor. They are a measure of ownership of production assets and a measure of growing economic globalization. A direct foreign investor may acquire voting rights in one undertaking by including in a wholly-owned subsidiary, acquiring shares in affiliated undertakings, merging, acquiring an unrelated entity or participating in the equity of a joint venture with another investor. Investment activity [6] is directly related to the level of economic security. Therefore, low 
investment activity can be seen as a direct threat to the economic foundations of development of an economy as it provides the sources of growth, generates revenues in the state budget and ultimately guarantees the financing of national security as a whole.

Table 3 Foreign Direct Investment Flows by Economic Sector in the Republic of Bulgaria annual data (EUR million)

\begin{tabular}{|l|r|}
\hline \multicolumn{1}{|c|}{ Economic sector } & $\mathbf{2 0 1 6}$ \\
\hline Administrative and support activities & 28.2 \\
\hline Mining industry & 12.0 \\
\hline Water supply; sewerage, waste management and restoration & -25.7 \\
\hline Other activities & -0.2 \\
\hline Culture, sport and entertainment & 7.0 \\
\hline Unclassified & 213.9 \\
\hline Education & -0.4 \\
\hline Total & 660.0 \\
\hline Real estate operations & -99.3 \\
\hline Manufacturing & 49.1 \\
\hline Production and distribution of electricity, heat and gaseous fuels & 55.7 \\
\hline Professional activities and scientific research & -58.8 \\
\hline Agriculture, forestry and fisheries & -5.3 \\
\hline Construction & 113.0 \\
\hline Creation and dissemination of information and creative products; telecommunications & 12.5 \\
\hline Transport, storage and mail & -13.1 \\
\hline Trade; repair of cars and motorcycles & 152.0 \\
\hline Financial and insurance activities & 20.1 \\
\hline Hotels and restaurants & 0.9 \\
\hline Human health and social work & 158.6 \\
\hline Source: & 1 . \\
\hline
\end{tabular}

Source: http://www.bnb.bg/Statistics/StExternalSector/StDirectInvestments/StDIBulgaria [2]

Table 3 and table 4 present official data on the flow of foreign direct investment by economic sector in the Republic of Bulgaria for 2016 in million euros and the flow of foreign direct investment in the Republic of Bulgaria. The data show that the most significant financial means are in the sectors - construction, trade, repair of motor vehicles and motorcycles and financial and insurance activities. It is noteworthy that fewer funds are invested human health and 
social work, culture, sports, entertainment and education.

The international data on foreign direct and investment levels by country as at 31
December 2016 are also presented. The data on the top ten receivers of FDI in the world and the location of the Republic of Bulgaria are presented below.

Table 4 Foreign Direct Investment Flow by Country /and position of the Republic of Bulgaria/ 31 December 2016 est.

\begin{tabular}{|l|l|c|}
\hline 1 & Netherlands & $\$ 4,759,000,000,000$ \\
\hline 2 & United States & $\$ 3,614,000,000,000$ \\
\hline 3 & United Kingdom & $\$ 1,858,000,000,000$ \\
\hline 4 & Hong Kong & $\$ 1,786,000,000,000$ \\
\hline 5 & Ireland & $\$ 1,411,000,000,000$ \\
\hline 6 & China & $\$ 1,391,000,000,000$ \\
\hline 7 & Germany & $\$ 1,391,000,000,000$ \\
\hline 8 & Switzerland & $\$ 1,217,000,000,000$ \\
\hline 9 & Singapore & $\$ 1,096,000,000,000$ \\
\hline 10 & Belgium & $\$ 1,054,000,000,000$ \\
\hline$\ldots$ & \multicolumn{2}{|c|}{} \\
\hline 55 & Morocco & $\$ 54,780,000,000$ \\
\hline 56 & Slovakia & $\$ 54,030,000,000$ \\
\hline 57 & Panama & $\$ 50,620,000,000$ \\
\hline 58 & Iran & $\$ 46,020,000,000$ \\
\hline 59 & Bulgaria & $\$ 45,260,000,000$ \\
\hline 60 & Croatia & $\$ 41,630,000,000$ \\
\hline 61 & Pakistan & $\$ 39,060,000,000$ \\
\hline 62 & Serbia & $\$ 39,020,000,000$ \\
\hline 63 & Tunisia & $\$ 37,340,000,000$ \\
\hline
\end{tabular}

Source: https://www.cia.gov/library/publications/the-world-factbook [8]

It is obvious that the first places are occupied by the Netherlands, USA, UK, Hong Kong, Ireland, China, Germany, Switzerland, Singapore and Belgium. The ranking also shows the total investment in Bulgaria's public and its place in the world, namely 59 position.

When assessing the level of foreign investment in the territory of any country from the point of view not only of economic but also national security, we should note that foreign direct investment increases the level of economic security in the host country, brings fresh financial resources, accompanied by high technology and a new organizational culture of economic activity as a whole. Foreign investment is also tied to the dynamics of economic growth. Countries with higher levels of foreign investment have higher GDP growth and hence higher economic growth; therefore the investments are a guarantee of economic security.

\section{Conclusion}

Economic security is a qualitative characteristic of the economic system that determines its ability to maintain normal living and working conditions for the population, and to provide sustainable resources for the development of the economy and the opportunity to 
consistently achieving national economic interests. The article discusses the foundations of economic security as a prediction for national and international security [5,7], the economy and economic reality in the Republic of Bulgaria, expressed by economic growth and investment activity as basic elements and economic security indicators. Economic security is closely linked to the notions of economic independence, stability and sustainability, and the ability for selfdevelopment and progress of the economic system. Economic security should generally be seen as a state of the national economy, whereby the economic foundations of development are protected and guaranteed and it is strongly related to the national and international security levels.

\section{References}

[1] Filipov, S., Contemporary Trends on the Labor Market in Bulgaria, New knowledge Journal of science, Academic Publishing House "Talent", University of Agribusiness and Rural Development - Bulgaria, 2016, pp.15-22.

[2] http://www.bnb.bg/Statistics/StExternalSector/StDirectInvestments/StDIBulgaria

[3] http://www.nsi.bg/bg

[4] Krastev K., Determinant Analysis of External Influence on the Bulgarian National Security Policy, The 22nd International Conference The Knowledge-Based Organization, Vol. 1, Sibiu, 2016, pp. 56-61.

[5] Petrova, E., A Review of the Expenditures on Defense of the Republic of Bulgaria for 2010-2015, Land Forces Academy Magazine, NR. 4 (80) / 2015, Nicolae Balcescu Land Forces Academy, Sibiu, Romania, 2015, pp. $488 \div 496$.

[6] Petrova, E., Value Investing - Essence and Ways of Finding Undervalued Assets, Sibiu, Romania, The 21st International Conference The Knowledge-Based Organization, Nicolae Balcescu Land Forces Academy, 2015, pp. $344 \div 348$.

[7] Petrova, E., Nichev, N., Financing and Place of the Bulgarian Army in Operations of International Crisis management, Land Forces Academy Magazine, NR. 3 (75), Sibiu, Romania, Nicolae Balcescu Land Forces Academy, 2014,pp. $307 \div 312$.

[8] The World Bank Group, Foreign Direct Investment - Net Inflows, International Monetary Fund, Balance of Payments Database, supplemented by data from the United Nations Conference on Trade and Development and Official National Sources, 2017, http://data.worldbank.org/ indicator

[9] Varbanova, B., Risks of Reduction of Currency Board in the Republic of Bulgaria, The Fifteenth International Scientific Conference under the topic „Knowledge in practice“ 15th to 17th of December, 2017 in Bansko, Republic of Bulgaria, ISSN 2545-4439, pp. 443-447.

[10] Zagorcheva D., D. Pavlov, The Need for Elaboration of a New Economic Model for Business Environment Analysis, Journal of Entrepreneurship \& Innovation, 8, 2016, pp. 19-27. 